\title{
Application of the Similar Function with Contribution of Semiotic Representations: A Research Study Involving High School Students
}

\author{
${ }^{1}$ Ceuma University-UniCeuma, Sao Luís, Brazil \\ ${ }^{2}$ Federal University of Maranhão-UFMA, Sao Luís, Brazil \\ ${ }^{3}$ State University of Maranhão-UEMA, Sao Luís, Brazil \\ ${ }^{4}$ Federal Institute for Education, Science and Technology, MA-IFFMA, Sao Luís, Brazil \\ ${ }^{5}$ Faculty of Maranhão-FACAM, Sao Luís, Brazil \\ Email: soflabidi@outlook.com, raimundolunaneres@gmail.com
}

Raimundo Luna Neres ${ }^{1,2}$, Sofiane Labidi1,2, Raimundo J. B. Brandão ${ }^{3}$, Willanickson J. S. Lago ${ }^{4}$ Renan T. P. Sampaio', Isabel Marques de Brito ${ }^{4}$, Lucimá Goes de Sousa², Ana Lúcia Maia Gama ${ }^{5}$

How to cite this paper: Neres, R. L., Labidi, S., Brandão, R. J. B., Lago, W. J. S., Sampaio, R. T. P., de Brito, I. M., de Sousa, L. G., \& Gama, A. L. M. (2018). Application of the Similar Function with Contribution of Semiotic Representations: A Research Study Involving High School Students. Creative Education, 9, 380-392.

https://doi.org/10.4236/ce.2018.93027

Received: February 8, 2018

Accepted: March 10, 2018

Published: March 13, 2018

Copyright $\odot 2018$ by authors and Scientific Research Publishing Inc. This work is licensed under the Creative Commons Attribution International License (CC BY 4.0).

http://creativecommons.org/licenses/by/4.0/

\begin{abstract}
In this work, we present a research carried out with focus on similar function and where we based our analyses on the records of semiotic representation. It is a qualitative research of an interventional character developed with students of the first year of the high school of a public college at the city of São Luís, MA, Brazil. This work has the aim to investigate the students' learning in the didactical and methodological use of the functions of conversion and handling records. The research data include a survey of the corpus of research, observations of data processing in the classroom and analyzes of the activities developed in class. We observed that the students who presented a better performance are those that transited in at least two different representations of the object of study.
\end{abstract}

\section{Keywords}

Similar Function, Records of Semiotic Representation, Learning, Conversion and Processing of Records

\section{Introduction}

This research, as a presupposition on the restlessness of the teachers and researchers, who over the years in their teaching practices, has observed the difficulties that the students of the first year of high school, mainly of public schools, 
face to appropriate the formal concept of function, as also to perform graphical interpretations of functions.

In this way, we tried to verify how would the processes of learning of similar function by the students of the first year of high school be developed when we adopt the records of semiotic representation as our theoretical and methodological approach? What contributions could the records of semiotic representation corroborate in the teaching and learning process of similar function?

In this context, the objective is to investigate how students appropriate the various ways of representing the object of study, as well as changing from one mathematical representation to another.

This research is justified, given that in the last decades, the process of teaching and learning mathematics in Brazil has been a reason for concern of the government, teachers and researchers considering the low rates of achievement in mathematics. Students from all levels of schooling have demonstrated difficulties in understanding contents related to this curricular component.

It is a qualitative research of an interventional character. The methodology consisted in experiencing how the conceptual understanding and the students' abilities occurs when they are solving problems involving similar function, in the light of semiotic representations.

The corpus of the research consisted of the observations and analyzes of the activities carried out in the classroom, through the records produced by the students and the logbook notes of the researchers. Data from these observations were recorded by the researchers for further analysis.

The analyses of student productions, related to the resolution of activities involving similar function, based on semiotic representations, were made through observations of the use of the treatment functions given to numerical, algebraic and graphical representations, as well as in relation to the change of a another record, for example, changing numerical data from a table to a graphical representation, or from a text to construct a mathematical sentence.

The role of the researcher teacher in the construction of knowledge is essential, since it can facilitate and narrow the theoretical relationship, practice and applicability of the contents in the daily life of the citizen and in the most diverse professions. Another important characteristic of teacher education is the reflection of the teacher in his pedagogical work.

The reflective process in teaching can be an opportunity for students to construct knowledge that contributes to the critical formation-reflective and conscious of their responsibilities in the society where they are inserted, and thus improve their citizenship.

Thus, both the teachers of the different knowledge areas and the teachers of mathematics, to perform well their role as mediator of the educational process favoring the student the knowledge construction, they must be well prepared in all aspects, whether related to the specific knowledge or related to the pedagogical and curricular knowledge. 
Among the obstacles that are relevant to the teaching and learning process of mathematics, the epistemological and the didactical obstacles deserve special attention. The firsts consist of a knowledge that leads to solutions adapted to certain contexts, although, it can also lead to wrong conclusions outside this context. According to Duroux (1983) and Bittencourt (1998: p. 14), this knowledge, "resists to the contradictions and often manifests again." While the didactic obstacles (Almouloud, 2007; Brousseau, 1989) are originated in the selections of the pedagogical strategies chosen and implemented by the teacher. According to Almouloud (2007: pp. 141-142), they allow the construction, during the learning process, of knowledge whose domain of validity is questionable or incomplete, and which will later prove to be obstacles to the development of the concept".

Looking for new paradigms and tools for teaching mathematics has been a great challenge for the Mathematics Education community, as with the evolution of science and technology, other ways of teaching and learning are necessary.

The dynamics of science and consequently of mathematical knowledge naturally led to the development of new ways to mediate the process and to the diversification of the records of representation of the study objects, enabling a better apprehension of these study objects. Semiotic representation records are important in the process of teaching and learning mathematics because in addition to being a communication system, it also facilitates a better organization of the information of the represented mathematical object.

Due to the student's need to use algebraic language as an essential language for the understanding of sciences, it's primordial to express the relation between greatness and to model problem situations, constructing descriptive models of phenomena with applicability in all knowledge areas. The function is one of the concepts of mathematics that is more studied currently.

\section{Methodological Aspects}

For a construction of the corpus of this research, we used the data collected by the students, from observations to the discounts when the similar function is constructed corresponding to each situation raised and from the application, in the classroom, of the activities involving the similar function, in the light of semiotic representations. This research took place during three classes lasting 100 minutes each.

This study involved students from two classes (A and B) of the 1st year of a high school (the Barjonas Lobão Integrated Unit), located in Jardim América neighborhood in the city of São Luís, MA, Brazil.

In the class $A$, from the 28 students matriculated, 24 students participated of all the activities (85.71\%). While in the class B, from the 27 students matriculated, 24 students participated of all the activities (88.89\%), making 48 participants, and therefore a significant sample of students in the two groups that participated in the research. 
Each group was divided into six groups: A, B, C, D, E and F, with four components each, to visit fairs, supermarkets, vehicle sales stores, construction and fishing equipment and pay existing in São Luís. Students carried out a survey of costs, prices of products, composition of salaries previously selected that would support the elaboration of corresponding mathematical sentences of each company visited. In the classroom, we randomly selected a vehicle dealership and two fish pay for the preparation of two activities, listed in this article.

Given the abstraction that exists in teaching the function concept, we took a review class in class-A, initially at extra hours, dealing with translation of Arithmetic, first-order equations, order and its graphical representation, transformation of written language into mathematical language, concepts of variable, variable dependent and independent relationship between them and binary relation. In the class-B, we took a little review of formal definition of function from the existence of two non-empty sets.

\section{Function Concept in Mathematics}

Innovate the teaching of mathematics is related to the development of new methodologies contemplating the programmatic contents with the purpose of favoring the development of the student's ability, creativity and autonomy, thus contributing to the construction of knowledge and making the student a critical and reflective thinking being (Kammi, 1995).

Based on this context, it's clear that the study of functions favors all those prerogatives listed by Kammi, since the contents related to functions are present in a large part of mathematics and other sciences and the understanding of the concept and its meaning is necessary for the apprehension of the mathematical object. This object of study is part of nature and is often used for modeling natural phenomena, which according to Gómez and Vilela (2007: p. 78) are intimately linked to the origins of mathematics and have appeared directly or indirectly in the great steps of the development of science.

Usually, natural phenomena are described and modeled mathematically. The function concept is very important for representing and estimating the actions of such phenomena. Given its importance in the everyday life and professional, the content of function is a mathematical object inserted in the Mathematics discipline in the official documents of the Brazilian education, as in the world in general.

In Brazil, the creation of the Mathematics discipline happened in 1929, resulting from the unification of three others, until then independent: Arithmetic, Algebra and Geometry (Braga, 2006) and the subject of Function was inserted in this discipline among the other contents.

The study of functions is important in academic formation, because it facilitates the student in the process of understanding natural and social phenomena. The study of functions allows the student to acquire algebraic language as the language of the sciences, necessary to express the relation between greatness and 
modeling problem situations, constructing descriptive models of phenomena and allowing making several connections within and out of mathematics itself (Brasil, 2002). Thus, the emphasis of the study of the different functions must be on the concept of function and its properties in relation to the operations, in the interpretation of its graphs and in the applications of these functions (Brasil, 2002: p. 121).

The study of functions here can be initiated with a qualitative exploration of the relations between two quantities in different situations: age and height; circle area and radius; time and distance traveled; time and population growth; time and range of motion of a pendulum, among others. It's also interesting to provoke the students to present other functional relationships and, at the outset, outline graphs representing these relationships, recording the types of growth and decrease (Brasil, 2006: p. 72). Thus, in order to better understand the conceptions of the mathematical function object it is necessary to understand the different types of languages present in Mathematical Education.

\section{Semiotic Representation System}

In order to, a semiotic system, could be considered a record of representation, according to Neres (2010) it should allow three fundamental cognitive activities linked to the semiosis: the formation of a representation identified as a representation of a given record, such as the a geometric figure; the treatment of a representation and the conversion of one representation into another.

According to Neres (2010), the transition from one system representation to another, that is, the simultaneous mobilization of several systems of representation, in mathematical activities, in general, it's not obvious for most students. The spontaneous transition from one semiotic representation to another only happens when they are congruent. This transition, according to Duval (2009), only occurs spontaneously in three situations, when:

a) There is a semantic correspondence between the significant units that constitute them.

b) There is the same possible order of apprehension of these units in the two representations.

c) There is conversion of a significant unit of the output representation into a single significant unit of arrival. The conversion is a different cognitive activity and is not subject to treatment activities.

From the mathematical point of view, in the records representation, the use of conversion plays an important role from a cognitive point of view (Freitas, 2003). Thus, in cognitive terms (Neres, 2014), the originality of mathematical activity it's in the fact that for each problem situation is related to the processes of conversion, because it is the conversion that leads to a better understanding.

On the other hand, Neres, Castro, \& Miguel (2017) also states that when the teacher uses new didactic resources and tries to represent the content taught in various ways, the learning perspective could reach the desired result. 
Therefore, care with the mathematical language is fundamental because it can be an instrument for a rational discussion of highly mathematical concepts, as it can convey realistic mataphors that hinder the scientific knowledge. The problems caused by the existing ruptures in the scientific language only tends to retain the student in the common knowledge, and influence his understanding that the science undergoes constant changes and rectifies its errors (Lopes, 2007).

Every kind of language has its representation and in mathematics is not different. The mathematical object can be represented in several ways. When, in a learning situation, a student has the ability to move between different types of representation records of the same object, in a problem of the same type, but in a different environment, it is expected, according to D'Amore (2007), that he will transfer the knowledge from one situation to another, in a natural, implicit, and spontaneous way, without any specific cognitive requirements for the new learning situation.

The various types of representation of a mathematical object are fundamental for conceptual learning and understanding of the meaning of this object. The student, when developing the ability to represent and identify an object in different representations, makes it easier to verify the relationships between the objects of study.

Thus, in the study of functions, it is necessary to promote the distinction between the concept of function, its meaning and its different types of representation, algebraic, graphic and natural language, etc.

The distinction between an object and its semiotic representation is a strategic point for the understanding of mathematics (Duval, \& Egret, 1993). Semiotics is a science whose object is to investigate the use of language through the different signs, called records of semiotic representations.

According to Neres and Brandão (2015), knowing the distinction between an object and its representation is fundamental for the understanding and learning of mathematical contents.

A sign is all that is related to a second thing, its object, with respect to a quality, so as to bring a third thing, its interpreter, to a relation with the same object, and so bring a fourth thing to a relation with that object in the same way, ad infinitum (Peirce, 2010).

Semiosis implies three cognitive activities of representation: the formation of representations in a semiotic record, the treatment and the conversions. For Duval (2009), this formation always implies a selection in the set of characters and determinations that we want to "represent", either to "express" a mental representation or to "evoke" a real object.

The treatment activity consists of transforming a representation within the same record, since the conversion activity occurs when the transformation produces a representation in another record.

According to Almouloud (2007), the treatment may, or not, results in algo- 
rithm. The one that results in algorithm presents operative rules for solving any equation. Already, the treatments that do not reduce to algorithms are those purely figurative or visual like the geometric figures (Andrade Filho, 2013). For the author, the objects that fall into the second case generally do not become learning objects, because they are classified as of second importance.

Instead, conversion is a transformation that enables moves from one record to another (Duval, 2008). It then requires the coordination of records in the subject who performs it. As example of conversion considering the transition from the graphic record to the algebraic record.

\section{Data Presentation and Analysis}

The analysis of the results of activities developed with a focus on similar function, elaborated and applied in the classroom had the purpose of verifying if the students developed competences to carry out treatment and conversion of semiotic representation records. From the activities carried out in the classroom, this article presents the analysis of two of them, one given by the students of class $B$ and another by the students of class $\mathrm{A}$, since it understands that it contemplates the proposed objectives.

In the mediation process between the researchers and the students, we verified that this kind of study of the similar function through the representation of mathematical records was widely accepted by the students. They considered it as a very productive novelty for them, because according to them, it's easier to understand the processes of graphical representation of a similar function, as well as making a change from one representation to another.

According to the group A of class B, constructed by the students DJ, PB, MR and TC, they had doubts when realizing the data collection of the research, because they asked if the collected data would serve to elaborate a mathematical equation (function) that corresponded to the reality of the situation raised.. These doubts, as a rule, were evident in all groups.

After a discussion with all the students of both classes to get their feedback, in a plenary session, and based on the data collected by them, we proceeded to select, at random, for the elaboration of corresponding mathematical equations. Only some of these data that best represented the object of the study and that we present in the form of activities.

\subsection{First Activity}

A car dealership pays its employees a fixed monthly salary of nine hundred of Brazilian currency Real, plus a commission of six hundred Brazilian currency Real for each vehicle sold. Based on this found information:

a) The law of formation (function) that allows to calculate the salary of the sellers.

b) The monthly salary of a seller who sells four vehicles?

c) How many vehicles will this seller need to sell to have a monthly salary of four thousand, six hundred and twenty Brazilian currency Real? 
The statement of this activity was given in a text format (expressed in natural language) and the student is asked to:

a) The conversion of the statement (natural language) to a numerical algebraic record.

b) The treatment of the algebraic record constructed in item (a) after the sale of four vehicles and,

c) Operational treatment from the numerical algebraic record constructed in item (a) to find the number of vehicles sold.

We observed that the students who participated in the mathematics revision were easier to understand the intuitive notion of function and its formal definition. They were able to associate the similar function with a relation of two variables that obey the law of formation, identifying "a" as of angular coefficient and $\mathrm{b}$ as linear coefficient.

The following is the resolution constructed by class B. In order to construct item (a), they considered R $\$ 900.00$ as a linear coefficient and 620.00 as an angular coefficient, and made the conversion of the natural language record, given in the statement of activity 1 , for the algebraic language obtaining the law of formation:

$$
f(x)=620 x+900 .
$$

For the item (b), since they had already found the record corresponding to the law of formation of the function, they performed the treatment within the built record itself, thus finding the salary of the seller on screen.

The students of group C of group B made the following comment on the answer they found: If the seller sells four cars, to calculate his salary we must substitute the function " $\mathrm{x}$ " for four and perform the calculations as follows:

$$
f(x)=620 x+900 \Rightarrow f(x)=620 \times 4+900 \Rightarrow f(x)=3.380,00 .
$$

Source: researchers archive (2016).

We observed that for some students, the construction of the response of item (c), the degree of difficulty was slightly higher, than in item (b).

We observed that class B students were able to mobilize mathematical knowledge better than class A students.

In a discussion with class B students about item (c), most stated that to calculate the number of vehicles to be sold to the seller to have a salary of $\$ 4,620.00$ was enough in the function $f(x)=620 x+900$, make $f(x)$ equal to 4.620 and solve the equation:

$$
\begin{aligned}
f(x) & =620 x+900 \Rightarrow 4.620=620 x+900 \\
& \Rightarrow 4.620-900=620 x \Rightarrow 3720=620 x . \\
& \Rightarrow x=\frac{3720}{620} \Rightarrow x=6
\end{aligned}
$$

Therefore, for the seller to have a salary of $\$ 4,620.00$ he would need to sell 6 automobiles. However, the results found by the students of class $\mathrm{A}$ in the three items were not as expressive as the results found by class B students. 
However, both Class A and Class B students had difficulty converting the algebraic record to the graphical record. It was observed that by assigning values to " $\mathrm{x}$ " they could not scale to put the results found on the axis-y.

The following is the resolution of Group C of class B, constructed by students AL, PP, MS and NC, for item (a).

They, mistakenly, wrote the law of formation: $f(x)=620 x+900$ this shows that they did not know how to convert the record given in natural language into the algebraic record. In this way, all other requested items were built erroneously.

Source: researchers archive (2016).

\subsection{Second Activity}

A couple on a given holiday decided to take their children to a fishery and pay. In the city there is the fish pay $(\mathrm{A})$ and the $(\mathrm{B})$ : In $(\mathrm{A})$ the entrance is twenty Brazilian currency Real per family and six Brazilian currency Real per pound of fish that they take.

In fish-pay (B) the entrance is ten Brazilian currency Real per family and eight Brazilian currency Real per pound of fish that they take.

Knowing that the total cost of a family in a fishery and paying is given according to the input and amount (in $\mathrm{kg}$ ) of fish that it carries. Based on this information find:

a) The Mathematics training law that allows calculating the total expenditure function for a family that goes to the fishery and pays (A).

b) Mathematical training law that allows calculating the total expenditure function for a family that goes to the fishery and pays (B).

c) How much will a family pay in the fish and pay it if they carry four kilos of fish?

d) How much will a family pay in the fish and pay-B, if it takes six kilos of fish?

e) In which situation do you go to Fish and Pay A or B? In what situations is it more advantageous to choose a fish? Why?

The statement was given as a registry-natural language-and students were required to convert this record to the numerical algebraic record in both item (a) and item (b). And from items (a) and (b) build the others.

The following is the resolution constructed by the students of group $\mathrm{F}$ of class A. For fish and pay A, they constructed the record, where q represents the quantity of fish to be taken and 20 represents the fixed entry rate. For the fish and pay $\mathrm{B}$ they built the log. In which $\mathrm{q}$, represents the quantity of fish to be taken and 8 the fixed rate of entry.

In items (c) and (d) students were required to perform the treatment operations in the records found in items (a) and (b). In order to answer (c) and (d) they substituted the value of " $q$ " by 4 in the equation and the value of " $q$ " by 6 in the equation, thus obtaining the numerical records: and expressed in Brazilian currency Real. 
In item (e), students were required to analyze the numerical records constructed in function of the hypotheses of the problem, so they would need to convert the algebraic record to the tabular and compare the numerical records found. This would enable them to analyze the results obtained. Given as a registry-natural language - and students were required to convert this record to the numerical algebraic record in both item (a) and item (b). And from items (a) and (b) build the others.

We verified that the students did not present any difficulty to construct the tables of values referring to the hypotheses of quantities of fish to be taken by each family. That is, they managed to exit the algebraic record to tabular registration correctly. However, some students faced obstacles to discover in which situation we don't need to choose the type of Fish Pay. They found using the table, but they did not know how to equate mathematically. That is, they could not see that it was enough to match the records constructed in Fish Pay A with the record obtained in Fish Pay B (cf. Table 1).

For Fontes and Palis (2014), these difficulties are not specific to high school students, but reach also some students of higher education, especially in the first periods in the discipline of Differential Calculus.

For Duval (2003), how diverse semiotic representations of a mathematical object are very necessary, because the mathematical objects are not "accessible to the perception or the intuitive experience, as they are common objects direct or physical". In this way, it is necessary to give representatives to these objects. The Table 1 shows an example, we present in Table 1 only the income of students in classes A and B, related to activity 2.

The data in Table 1 corroborate with what was observed when students constructed the results of activity 2, mainly in relation to item (e), in which the students of both Class A and Class B presented difficulties of understanding and doing the analysis of the situation proposed in the activity.

\section{Conclusion}

Starting from the premise that a new knowledge is constructed from new information connected to pre-existing knowledge, we verified in this work that that the fact that the students do not know or do not remember certain concepts, doesn't imply that these students do not have any knowledge. It's evident that if students have knowledge of meanings and elementary mathematical content, this helps them to overcome many obstacles when solving a mathematical problem.

Table 1. Acertos dos alunos das turmas A e B na atividade 1.

\begin{tabular}{|c|c|c|c|c|c|c|c|c|c|c|c|}
\hline \multirow{2}{*}{$\mathrm{T}$} & \multirow{2}{*}{$\mathrm{F}$} & \multicolumn{2}{|c|}{ Item (a) } & \multicolumn{2}{|c|}{ Item (b) } & \multicolumn{2}{|c|}{ Item (c) } & \multicolumn{2}{|c|}{ Item (d) } & \multicolumn{2}{|c|}{ Item (e) } \\
\hline & & $\mathrm{f}$ & $\%$ & $\mathrm{~F}$ & $\%$ & $\mathrm{~F}$ & $\%$ & $\mathrm{f}$ & $\%$ & $\mathrm{f}$ & $\%$ \\
\hline A & 24 & 21 & 87,5 & 21 & 87,5 & 20 & 83,33 & 19 & 79,17 & 14 & 58,33 \\
\hline B & 24 & 14 & 58,33 & 13 & 54,17 & 11 & 45,83 & 10 & 41,67 & 5 & 20,83 \\
\hline
\end{tabular}

Fonte: Dados da pesquisa; T: turmas, F: total de alunos por turma, f: total de acertos. 
We also verified that the students' lack of previous knowledge could impair their learning process. Throughout our academic life, we observed that, in the majority of cases, the learning process is constructed within an organized and significant system but in a repetitive way, carrying out copies of activities, without an understanding of the mathematical object and its application in diverse contexts.

Generally, the access to mathematical objects takes place through conversions established in the various types of representations. In this way, it is necessary to develop different ways of representing the object of study, just as the challenges for developing a solution will become easier.

We consider that this research contributes to the development of the knowledge and the student's learning, also pointing out the relevance of the use of this type of research and construction of the activities based on the data collected by them. The exploration of this didactic material favored the understanding that the use of different representations of the mathematical object-functions-helps the conceptual and formal understanding of the similar function. The research carried out by the students also allowed for the transformation of operations indicated in three types of language: the natural, formal and figurative language used to represent the similar function from the actual data collected by the students.

In addition, in the research process, when exploring the making of tables, it was intended to support them to solve activities that require more mathematical skills, and this allowed them to discover new resolution heuristics.

We should note also that the math teachers, generally, don't work with field research to promote learning. They only mobilize the bookish representations, since, normally, they were not prepared to work also with the conversion between semiotic records. This fact, according to Duval (2011), can hinder the student's cognitive development and consequently leads to the non-strengthening of learning in mathematics.

It was possible to verify that there was learning, which confirms what Duval (2011) says that if the student can mobilize at least two semiotic records and operate them, it's because there was learning.

The data show that the majority of the students were able to make the conversion of the given record into a natural language for the numerical record, or vice versa, and with some of the activities using the field data that gave them the knowledge and understanding of a new teaching material, previously unknown to them.

However, it is recognized that teaching based on the mobilization of a diversity of records can't and should not be considered as the solution for teaching mathematics. It's understood that it is another methodology, an alternative to develop skills and competences in the mathematical activities, thus contributing to the student's cognitive development. 


\section{References}

Almouloud, S. Ag. (2007). Fundamentos da Didática da Matemática (1st ed.). Curitiba. PR: Editora UFPR.

Andrade Filho, D. M. de (2013). Processos de conversão de registros em língua natural para linguagem matemática: Análise com base na teoria da relevância. Dissertação de Mestrado, Tubarão, SC: Universidade do Sul de Santa Catarina.

Bittencourt, J. (1998). Obstáculos Epistemológicos e a Pesquisa em Didática da Matemática. In Educação Matemática em Revista. São Paulo: SBEM.

Braga, C. (2006). Função: a alma do ensino da matemática. São Paulo: Annablume; FAPESP.

Brasil (2002). Ministério da Educação. PCNs +. Ensino Médio. Orientações Educacionais Complementares aos Parâmetros Curriculares Nacionais. Ciências da Natureza, Matemática e suas Tecnologias.

Brasil (2006). Ministério da Educação, Secretaria de Educação Básica. Ciências da natureza, matemática e suas ORIENTAÇÕES CURRICULARES PARA O ENSINO MÉDIO Ciências da Natureza, Matemática e suas Tecnologias. Brasilía, DF.

Brousseau, G. (1989). Les obstacles épistémologiques et la didactique des mathématiques. In N. Bednarz, \& C. Garnier (Eds.), Construction des savoirs: Obstacles \& conflicts. Colloque International obstacle épistémologique et conflit sócio-cognitif. Montreal: Agence d'ARC Inc.-CIRADE.

D’Amore, B. (2007). Elementos de didática da matemática. Tradução: Maria Cristina Bonomi. São Paulo: Ed. Livraria da Física.

Duroux, A. (1983). La valeur absolue: Difficultés majeures pour une notion mineure. In Petit Ed.), x, n.3 (p.14).

Duval, R. (2003). Registros de Representação Semióticas e funcionamento cognitivo da compreensão em matemática. In S. D. A. Machado (Ed.), Aprendizagem em Matemática: Registros em representação semiótica (pp. 11-33). Campinas: Papirus.

Duval, R. (2008). Registros de representações semióticas e funcionamento cognitivo da compreensão em matemática. In S. D. A. Machado (Ed.), Aprendizagem em matemática: Registros de representação semiótica (4th ed., pp. 37-78). Campinas: Papirus.

Duval, R. (2009). Semiósis e pensamento humano: Registros semióticos e aprendizagens intelectuais. Trad. de Lênio Fernandes Levy e Maria Rosâni Abreu da Silveira. São Paulo: Livraria da Física. Coleção Contextos da Ciência, fascículo 1.

Duval, R. (2011). Ver e Ensinar a Matemática de Outra Forma-entrar no modo matemático de pensar: Os registros de representaçóes semióticas. São Paulo: PROEM.

Duval, R., \& Egret, M. A. (1993). Introduction à la démonstration et apprentissage du raisonnement déductif. Repères, 12, 114-140.

Fontes, R. B., \& Palis, G. de la R. (2014). Trabalhando com funções em mais de um contexto e discutindo a articulação com outros campos. VIII Encontro Nacional em Educação Matemática: Educação matemática um compromisso social, Recife-Pe.

Freitas, J. L. M. de. (2003). Registros de representação na produção de provas na passagem da aritmética para a álgebra. In S. D. A. Machado (Ed.) Aprendizagem em matemática: Registros de representação semiótica (pp. 113-124). Campinas: Papirus.

Gómez, J. J. D., \& Vilela, M. L. T. (2007). Pré-Cálculo (Vol. 2, Módulos 3 e 4. 4. ed.). Rio de Janeiro: Fundação Centro de Ciências e Educação Superior a Distância do Estado do Rio de Janeiro. 
Kammi, C. (1995). Desvendando a aritmética: Implicações na teoria de Piaget. Campinas: Papirus.

Lopes, A. R. C. (2007). Currículo e epistemologia. Ijuí: Unijuí.

Neres, R. L. (2010). Aplicação dos registros de representação semiótica no ensino-aprendizagem da matemática: Um estudo com alunos do sexto ano do ensino fundamental. Doutorado em Educação, Marília: Faculdade de Filosofia e Ciências, Universidade Estadual Paulista.

Neres, R. L. (2014). Aprendizagem Matemática usando Registros Semióticos. Revista Areté, 7, 72-82.

Neres, R. L., \& Brandão, R. J. B. (2015). Sistema de Numeração: Ensino-aprendizagem com aporte na teoria histórico-cultural. Pesquisa em Foco, 20, 172-186.

Neres, R. L., Castro, E. R., \& Miguel, J. C. (2017). Mathematics in the Initial Years of Fundamental Teaching in Brazil: An Experience with Teachers in Training in the Pedagogy Course. Creative Education, 8, 607-626. https://doi.org/10.4236/ce.2017.84047

Peirce, C. S. (2010). Semiótica. Tradução de José Teixeira Coelho Neto (4th ed.). São Paulo: Perspectiva. 